\title{
The conversion of the cardinal? Pride and penitence in some Tudor histories of Thomas Wolsey
}

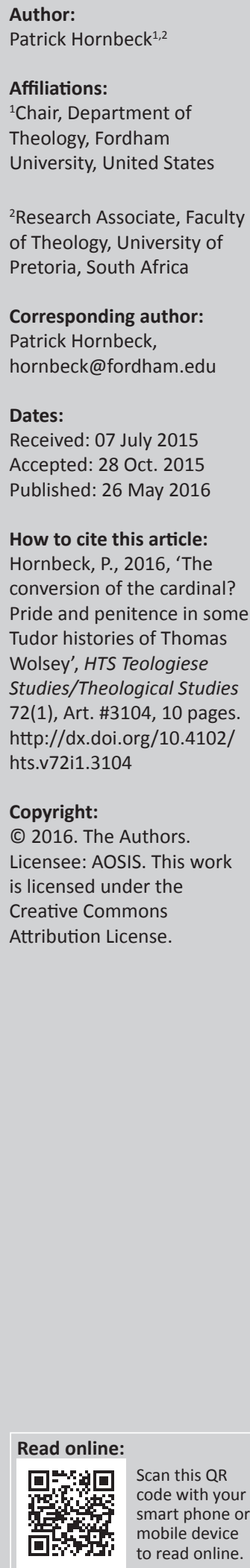

The life of Cardinal Thomas Wolsey, lord chancellor of England from 1515 to 1529, has inspired no small number of literary, historical, and dramatic retellings. A comprehensive study of these texts remains to be written, but this article seeks to make a start by examining how Tudor writers portrayed the cardinal's response to his deposition and subsequent disgrace. For some authors, Wolsey's fall only made him more proud, and he began to act erratically and disloyally, confirming the wisdom of the king's decision to relieve him of office. For others, deposition moved Wolsey to become philosophical and penitent, and some such writers depict a cardinal who at the end of his life underwent nothing short of a conversion. This article traces both of these historiographical trajectories from their origins in writings of the late 1540s and 1550s through a range of late Tudor chronicle accounts. Elements of both narratives about the cardinal appear, prominently if not always congruously, in one of the best-known theatrical works about the events of the reign of Henry VIII, the play King Henry VIII (All Is True) by William Shakespeare and John Fletcher. Understanding the interrelationships between the Tudor texts presented here is essential to grasping later portrayals of Wolsey and his contemporaries.

Professor Graham Duncan is by origin a Scottish Presbyterian, so there may appear to be something incongruous about writing in his honour a study of an English cardinal whose reputation over the centuries has been more that of sinner than saint. However, Professor Duncan has also been a thoughtful reader of Roman Catholic texts, especially the groundbreaking documents of the Second Vatican Council (1962-1965), and not unlike many of his 16th-century forebears he has been outspoken when reform has been needed in his church communities, so I hope that he will take delight rather than offense at these pages dealing with the depiction of Thomas Wolsey in a range of chronicles and plays from the Tudor period.

Cardinal Wolsey (c. 1473-1530), who served among other roles as archbishop of York (1514-1530) and lord chancellor of England (1515-1529), was King Henry VIII's closest and most trusted advisor during the first half of his reign. Wolsey's influence during the period of his chancellorship was so great that some of his supporters did not hesitate to apply to him language traditionally reserved for monarchs: '[I]n great honour, triumph, and glory he reigned a long season, ruling all thing within this realm appertaining unto the King by his wisdom' (Cavendish 1962:26). Yet the close of Wolsey's life was marked by disgrace. Dismissed as chancellor in 1529, he languished for a year in exile from the royal court before being permitted to go to his archdiocese, where in a short span of time he was arrested on charges of high treason, ordered to return to London for trial, and died en route. Since the time of Wolsey's death, historians have speculated about the causes of his fall: was it his failure to obtain for the king the annulment of his marriage with Katherine of Aragon, was it his apparent disdain for the king's intended bride Anne Boleyn, had he betrayed Henry's trust, or all of the above? Questions have also been asked about the manner of his death: some sources report that he committed suicide, while others invite pity for a loyal servant who was deserted by his king and died of shock and a broken heart.

On a broader stage, Wolsey has often served as a foil in the historiography of the Henrician Reformation, and indeed in that of English Catholicism. In the 16th century, evangelical ${ }^{1}$ writers almost universally held Wolsey up as the image of what was wrong with Roman Catholicism: here was a (supposedly) bloated prelate who never set foot in his archdiocese until the year of his death, who was more obedient to Rome than to his king, and whose personal pride and arrogance knew no bounds. Those of Catholic sympathies were split, some seeing Wolsey as an able administrator who instituted necessary reforms and managed England's affairs while the king

1.In using the term 'evangelical' for those who would later be called Protestant, I follow MacCulloch's (2004:xviii) suggestion that scholars embrace the terminology of the second quarter of the 16th century as a way of avoiding anachronism. 
was distracted by worldly pleasures, but others affirming with their Protestant counterparts that Wolsey's self-interest helped cost the Roman church England's obedience. Similar differences in interpretation appear in modern histories as well; for instance, Dickens's classic The English Reformation repeats early modern criticisms that Wolsey's (1989:61) leadership was characterised by 'tactlessness', a 'voracious appetite' for land and power, and 'personal arrogance'. Much to the contrary, revisionists such as Scarisbrick seek to see both good and bad in Wolsey (1968:240): 'For all his faults, he had deserved more generous treatment from his king, and has, perhaps, deserved more generous treatment from some historians. $^{2}$

A comprehensive study of the character of Wolsey in historical writing and drama remains to be written, but this article seeks to make a start by examining how Tudor writers portrayed the cardinal's response to the reversal of his fortunes around the year 1529. ${ }^{3}$ The earliest accounts appear to be divided on the question of how Wolsey reacted to his deposition and exile: for some authors, his pride only increased, and he began to act erratically and disloyally, confirming the wisdom of the king's decision to relieve him of office. For others, deposition made Wolsey philosophical and penitent, and some such writers depict a cardinal who at the end of his life underwent a conversion. Elements of both of these historiographical trajectories can be found in one of the best-known dramatizations of the events of the period, the play King Henry VIII (All Is True) by William Shakespeare and John Fletcher.

The first extensive accounts of Wolsey's life were not published until the late 1540s, nearly two decades after his downfall and death, perhaps out of concern that Henry VIII might react adversely to texts that excessively lionised - or demonised - a figure about whom he appeared to retain mixed feelings. In 1548 the first edition of Edward Hall's Union of the Two Noble and Illustre Families of Lancaster and York, known commonly as Hall's Chronicle, appeared; a revised edition was published in $1550 .{ }^{4}$ Hall was a member of the 'Reformation Parliament', which among other acts charged Wolsey with praemunire (illegitimately maintaining the supremacy of papal jurisdiction) and adopted the Act of Supremacy that declared the king to be the supreme head on earth of the Church of England. ${ }^{5}$ His chronicle, as we will see, is both anti-Roman and anti-Wolsey. Edwards (2014) has

2.Among the few pre-20th-century historians who were sympathetic to Wolsey Gairdner (1899) stands out. The final quarter of the 20th century was notable Gairdner (1899) stands out. The final quarter of the 20th century was notable
for revisionist work on the English Reformation(s), but not all revisionists believed for revisionist work on the English Reformation(s), but not all revisionists believed
it appropriate to soften longstanding criticisms of the cardinal. For Haigh (1987:56-74), for instance, 'no charge against Wolsey was too gross to be possible,' but 'Wolsey was not the church,' and indeed the pre-reformation church was not nearly as corrupt as evangelical polemicists claimed. For Duffy (2005) Wolsey merits no more than passing mention in either edition of his influential The stripping of the altars.

3.I am currently preparing a study of the treatment of Wolsey in a wide selection of historical, literary, and dramatic works from the mid-sixteenth to the early 21st centuries.

4.The second edition is STC 12723. On the printing history of Hall's Chronicle, see Pollard (1932).

5.For background on the charges presented against Wolsey and, after his fall, against other senior clergymen as well, see Guy (1982). On the various statutes of praemunire more broadly, the classic study, Waugh (1922) remains helpful. suggested that it was the publication of Hall's Chronicle that spurred GeorgeCavendish, Wolsey's former gentleman-usher, to write between 1554 and 1558 his far more laudatory version of the cardinal's life, Thomas Wolsey, Late Cardinall, His Lyffe and Deathe. ${ }^{6}$ Elements from both Hall and Cavendish made their way into many Elizabethan histories, including John Foxe's Actes and Monuments (multiple editions from 1563), Raphael Holinshed's Chronicles of England, Scotland, and Ireland (1577, revised 1587 after Holinshed's death), and John Stow's Annales of England (1592). ${ }^{7}$ Foxe's book evolved from edition to edition, and the composition of Holinshed's and Stow's texts was also affected by shifts in the political and ecclesiastical context: Holinshed's chronicle was censored by the Privy Council, and Stow worked hard to distance himself from the most extreme of his evangelical contemporaries, although it earned him suspicion of being a secret Roman Catholic (Beer 2004; Clegg 2015). In their own turn, the writers of King Henry VIII, Shakespeare and Fletcher, drew upon material from Holinshed, Foxe, Stow, and John Speed's History of Great Britain. ${ }^{8}$ Yet, in considering the playwrights' relationship to their sources, editor Gordon McMullan's caveat is an important one:

Shakespeare and Fletcher do not just use their historical sources.... On the contrary, there are, in the process of creating new drama from other dramatic or non-dramatic texts, principles of selection and omission which inevitably constitute an interpretation of those texts. (Shakespeare \& Fletcher 2000:162, original emphasis)

Therefore, the nuanced if occasionally unstable portraits of Wolsey, Henry, and other characters in the play are, in the final analysis, the playwrights' own creation.

These six sources - Hall, Cavendish, Foxe, Holinshed, Stow, and Shakespeare/Fletcher - are by no means the only historical or dramatic texts from the Tudor period that depict Wolsey's fall, but they are and have been among the most influential ones, and they represent the full spectrum of contemporary opinion about the cardinal and the possibility of his conversion. ${ }^{9}$ Therefore, they form the basis for the historiographical analysis that follows.

\section{Crafting the case for and against Wolsey: Edward Hall and George Cavendish}

Edward Hall (1497-1547) was one of the first writers to produce an extended history of the reign of Henry VIII, a reign that he witnessed at close quarters as a London official

6.As Wiley (1946) explains, Cavendish's text influentially circulated in manuscript for nearly a century before being printed in a highly expurgated edition of 1641 .

7.Foxe's 1570 edition will be the subject of discussion here: STC 11223; the 1587 edition of Holinshed is STC 13569.5; and Stow is STC 23334.

8.The 1614 edition of Speed's History is STC 23046. On the authorship of Henry VIII, see below, n. 18. 9. Limitations of space have made it necessary to exclude many texts, including the
poems of John Skelton; Polydore Vergil's Anglica historia; polemics by Robert Barnes, Simon Fish, and William Tyndale; Samuel Rowley's play When You See Me, You Know Me; the collection of poems Mirror for Magistrates; and, in the early 17th You Know Me; the collection of poems Mirror for Magistrates; and,
century, Speed's History and William Vaughan's The Golden-grove. 
and Member of Parliament. Hall's Chronicle, as Herman has noted, focuses in large part on secular rather than ecclesiastical politics; it pays close attention to the fortunes of Londoners and, in particular, those of London merchants (2012). Hall was still at work on his magnum opus at the time of his death in 1547, and in his will he left instructions that the printer, Richard Grafton, should complete and publish the text. There is some debate about the extent of Grafton's interventions, but it appears clear that Hall's own contributions run through at least the 24th year of King Henry's reign (1533/34) (Pollard 1932). It is therefore not unreasonable to attribute to Hall himself the chronicle's treatment of Wolsey.

Wolsey is a more or less constant presence in Hall's Chronicle from the time of his first appearance in Henry's fifth regnal year $(1514 / 15)$ through the time of his death. Until 1528 Wolsey is the king's almost untouchable alter ego. For example, when in 1518 a delegation from the city of London comes to Henry to beg pardon for a riot that had recently taken place, the king refuses to deal with them: ' $[A] \mathrm{t}$ this tyme we wyll graunt to you neither our favor nor good will, nor to thoffenders mercy, but resort to the Cardinall our lord Chau[n]celour' (Hall 1550: fol. lxiii ${ }^{\mathrm{r}}$ ). Wolsey sits at the king's right hand in parliament, he prepares the way for the king's trips abroad, he entertains foreign ambassadors on Henry's behalf, and he repeatedly reorganises the royal household. In the church he dissolves the convocation of clergy in Canterbury province when he believes that it is threatening his authority as papal legate (fols $\mathrm{cvi}^{\mathrm{r}}, \mathbf{l x x}^{\mathrm{r}}$, lxxxxiir $\left.{ }^{\mathrm{r}}, \mathrm{clxiii}^{\mathrm{v}}, \mathrm{clxvi}^{\mathrm{r}}, \mathrm{cx}^{\mathrm{v}}\right)$. Moreover Wolsey's dominance is not confined to England: the French king, Francis I, sends him a 'patent of power' that was 'taken for great loue that the Frenche kyng had geuen so greate power to the kynge of Englandes subiect' (fol. $x_{x \times v^{r}}$ ).

Even before Hall first notes the public's dislike of the cardinal, he points out Wolsey's vices: pride, arrogance, and an inability to tolerate rivals. Hall's Wolsey becomes chancellor by politicking his predecessor, Archbishop of Canterbury William Warham, out of the post: Warham resigns after 'perceauing that the Archebyshop of Yorke medled more in his office of Chauncelourship then it became hym to suffer' (fol. lvii ${ }^{\mathrm{v}}$ ). Likewise, when papal legate Lorenzo Campeggio comes to England in 1519/20 to seek Henry's support for the pope's wars, Wolsey, 'whose ambicion was neuer satisfied', insisted upon being made legate as well (fol. lxiiiir). In the early 1520s Hall's Wolsey squares off repeatedly with the House of Commons over royal taxation, earning the enmity of Hall's beloved London merchants. In his dealings with parliament Wolsey is portrayed as engaging at best in what modern politicians call spin; judged more bluntly, he is lying outright when he claims that it was not just him but the king's whole council who in 1525 sought an unprecedented 'benevolence', the 'Amicable Grant'.

But the people toke all this for a mocke, and saied God saue the kyng, for the Cardinal is knowen wel inough, the commons would heare no prayse spoke $[n]$ of the Cardinall, they hated hym so muche. (fol. cxliir)
The Amicable Grant represents the first downward turn in the fortunes of Hall's Wolsey. Previously barely tolerated in Hall's narrative, now he is roundly ridiculed: he is a 'Bochers dogge $\mathrm{e}^{\prime 10}$ living in a royal palace; he is a killjoy who legislates against dice and cards; and he is paranoid, imagining that a play performed at Gray's Inn was an allegory against him: '[Y]et it was neuer meante to hym ... wherefore many wysemen grudged to see hym take it so hartely' (fols cxliiiir ${ }^{\mathrm{r}}$, cxlix $^{v}$, cliiiiv ${ }^{v}$. This unfortunate entertainment, recorded under the year 1526/27, coincides with Hall's first allusion to Henry's divorce from Katherine of Aragon. Yet curiously, in light of later historiography, it is not Wolsey's involvement in the king's 'great matter' that leads to his downfall, but instead his mismanagement of Henry's foreign policy. In the late 1520s, Hall's Wolsey becomes a symbol for the excessive involvement of foreign powers in England's affairs. First, the cardinal persuades the king to send a substantial sum of money to support the besieged Pope Clement VII, about which Hall comments that 'of this charge the realme shall not be one peny the better ... [the pope] neuer shall do us good' (fol. clxiiiiv ${ }^{v}$ ). At the same time, Wolsey is too closely identified with the French: he 'was al Frenche', and in negotiations with the French 'ye Cardinal was euer on the French part' (fols $\left.\mathrm{clxv}^{\mathrm{r}}, \mathrm{clxxv}^{\mathrm{r}}\right)$. Yet Henry's opinion of the cardinal begins to change decisively when he is confronted with evidence that Wolsey has played him false - letters that the cardinal had sent to the emperor's ambassadors in which he recommended a policy different from the king's. Hall's narrative of Henry's reaction to the bearer of this news bears repetition:

$[H]$ e mused a great while, and saied: O Lord Jesu, he that I trusted moste, tolde me all these thynges $\operatorname{co}[n]$ trary, well Clarenseaux, I will be no more of so light credence hereafter, or nowe I see perfectly, that I am made to beleue the thing that was neuer done. Then the kyng sent for the Cardinall and priuily talked with hym, but whatsoeuer he saied to hym, the Cardinal was not very mery, and after that tyme, the Kyng mistrusted hym euer after. (fol. clxxiii ${ }^{\mathrm{r}-\mathrm{v}}$ )

Henry's suspicion becomes all the greater when the legatine court to investigate the legitimacy of his marriage encounters delays. Sensing an opportunity, Wolsey's long-embittered enemies among the nobility present the king with a book of the cardinal's misdeeds.

When the kyng saw the boke... he euidently perceived the high pride and couetousnes of the Cardinal, and saw openlye with what dyssymulacion and clokyng, he had ha[ $n]$ deled the Kinges causes. (fol. clxxxiii ${ }^{\mathrm{r}-\mathrm{v}}$ )

Indicted for praemunire, forced out of his home of York Place, and in exile from the court at his episcopal residence at Esher, Hall's Wolsey appears to accept responsibility for his actions when he pleads guilty to the many charges against him (fol. clxxxx $)$. Whatever repentance this might imply is short-lived, for in the last months of his life, the cardinal wages a campaign of retribution and complaint. In Hall's telling, Wolsey undertakes to travel northward and establish

10.That Wolsey was the son of a butcher is a commonplace, but an unsubstantiated one. Robert Wolsey may instead have been a grazier and not as poor as the traditional historiography imagines. See Cameron (1888:459-460). 
himself in his diocese, but even after Henry grants him permission to do so, the cardinal 'continued this yere euer grudgying at his fall as you shall here after' (fol. clxxxxi ${ }^{\mathrm{v}}$ ). Once in York, Wolsey is nothing short of seditious:

[he] wrote to the Court of Rome and to divers other prynces letters in reproche of the kyng.... The Cardinal also woulde speake fayre to the people to wynne their heartes, and declared euer, that he was uniustlye and untruely ordered... and to gentlemen he gaue great gyftes to allure them unto him. (fol. clxxxxiiiir ${ }^{r}$

The king orders the cardinal's arrest, yet Wolsey resists almost to the end, claiming that as a papal legate he is not subject to royal authority and that he had already been forgiven his praemunire, a crime into which he only 'by negligence fell' (fol. clxxxxiii ${ }^{r-v}$ ). Even though the cardinal does eventually submit to arrest, Hall goes so far as to imply that Wolsey wilfully frustrates the king's justice by hastening his own death before he can return to London for trial (fol. clxxxxiiii ${ }^{\mathrm{v}}$ ).

Unsurprisingly, Hall's overall verdict on Wolsey is a negative one. More than one of the chroniclers whose texts we will be reviewing borrow from Hall's assessment in framing their accounts of the cardinal:

This Cardinall as you may perceuyue in this story was of a great stomacke, for he compted him selfe egall with princes, and by craftye suggestion gatte into his hands innumerable treasure; $\mathrm{He}$ forced little be simony \& was not pitiful and stode affeccionate in his owne opinion: In open presence he would lye and say untrueth and was double both in speche and meaning: He would promise much and performe lytle: He was vicious of his body and gaue the clergie euyl example: He hated sore the citie of London and feared it. The authoritie of this Cardinal set the clergie in such a pride that they dysdayned al men, wherefore when he was fallen thei followed after as you shall heare. (fol. clxxxxiiiiv)

The last clause of this passage is perhaps the most telling from a broader historiographical perspective, because for Hall the fate of Wolsey prefigures the fate of the Roman church in England. Both were deceptive and decadent; both were inimical to Hall's beloved city of London. And both fell once the king learned the true state of affairs. Indeed, not only in this passage but elsewhere Hall makes it clear that he believes Wolsey's greatest fault to have been that he considered himself beyond the king's jurisdiction: here Hall notes that Wolsey 'compted him selfe egall with princes', and Hall presents a Wolsey who speaks for the king, levies taxes without the king's knowledge, sends English money outside the realm, and even in one scene uses the royal 'we' in giving instructions concerning the meeting of Kings Henry and Francis in France (fol. lxx $x^{r}$ ). Yet in contrast to later writers, Hall's criticisms of Wolsey are more political than personal: certainly Hall does not hesitate to condemn Wolsey, but he is innocent of the disparaging anecdotes that other anti-Wolseian writers gleefully recount, and likewise he refrains from insulting remarks about Wolsey's physical appearance.
Hall's Chronicle was first published in 1548, when the accession of the young Edward VI was raising hopes that England would become a fully Protestant nation, and when English was just about to emerge as a liturgical language in the first edition of Thomas Cranmer's Book of Common Prayer (1549). Protestant hopes were dashed by Edward's untimely death in 1553, and Hall's text was temporarily among the casualties: a 1555 decree of Queen Mary's put it on a list of books to be destroyed, but it was rehabilitated in the reign of Mary's half-sister, Elizabeth (Herman 2012). In the meantime, though, a contrary perspective on Cardinal Wolsey had been articulated for the first time: that of the late cardinal's gentleman-usher, George Cavendish (1494-1562?).

The modern editors of Cavendish's Life have pointed out that the text

stands out uniquely among sixteenth century accounts of the Cardinal, for it is no exaggeration to say that both Protestant and Catholic writers of the period tend to treat Wolsey as the most despicable of men. (Sylvester \& Harding 1962; see also Sylvester 1960)

The Life is a personal as well as political portrait of its subject, and Cavendish uses rhetorical techniques and hermeneutical lenses that differ greatly from Hall's. Even though it is probable that Cavendish consulted Hall in writing his text, it should go without saying both that Cavendish's vantage point was not the same as Hall's, and that his role as one of Wolsey's most intimate servants afforded him a measure of access to and sympathy for the cardinal that would have been impossible for an evangelical-leaning London MP (Anderson 1984:36-37).

As many scholars have noted, Cavendish's principal interpretive schema for Wolsey's rise and fall is that of Fortune's wheel (Edwards 2014; Sylvester 1960:45). Fortune 'followeth some whom she listeth to promote, and even so to some her favor is contrary, though they should travail never so much with urgent diligence and painful study' (Cavendish 1962:11). It is by Fortune that Wolsey first rises in the service of King Henry VII, for whom he famously completes in 3 days a mission to the emperor that would take another man many more, ${ }^{11}$ and by Fortune likewise that Wolsey became prominent enough by the time of Henry VIII's accession that the young king was able to see him as 'a meet instrument for the accomplishment of his devised will and pleasure' (p. 12). But Fortune also brings about Wolsey's downfall, for at the time of the cardinal's greatest influence

Fortune (of whose favor man is no longer assured than she is disposed) began to wax something wroth with his prosperous estate - thought she would devise a mean to abate his high port; wherefore she procured Venus, the insatiate goddess, to be her instrument to work her purpose. (p. 30)

It is Anne Boleyn, not just her supporters among the nobility, who in Cavendish's account brings Wolsey down. She does so

11.The veracity of Cavendish's report, though he claims to have heard this story directly from the fallen Wolsey, has long been questioned for lack of corroborating evidence: see Cameron (1888:470-471). 
not out of evangelical commitment but rather out of personal jealousy, for she resented Wolsey for intervening, at the king's command, to break off her early engagement to Henry Percy, the son of the Earl of Northumberland (p. 36). ${ }^{12}$ The 'great lords of the council', who in Hall were Wolsey's primary enemies, in Cavendish take advantage of Anne's vindictiveness and her position as the object of the king's affection to drive a wedge between Henry and his chancellor (pp. 38, 98).

Wolsey's fall from power occupies a disproportionate section of Cavendish's narrative; it comprises more than half of the printed text of the Life, is in equal parts moralising and moving, and, as several commentators have noticed, takes not a few cues from the narrative of Christ's passion (Anderson 1984; Steiner 1952-53). ${ }^{13}$ Cavendish's fallen Wolsey is hardly like his counterpart in Hall's Chronicle. The cardinal asserts his innocence of the charges against him yet deliberately humbles himself by not contesting them before the king. Wolsey's words to his treasurer at the time of the confiscation of his goods are emblematic:

I would all the world knew, and so I confess, to have nothing, either riches, honour, or dignity, that hath not grown of [the king] and by him; therefore it is my very duty to surrender the same to him again as his very own with all my heart, or else I were an unkind servant. (p. 103)

The disgraced cardinal shows other signs of repentance as well: he sheds tears that he cannot compensate his household staff; he never speaks against Henry or Anne; and he rejoices at any sign that he might be restored to royal favour, as in the memorable scene where he kneels in the dirt before Sir Henry Norris, a member of the king's privy chamber, who has come to bring Wolsey a ring symbolising the king's on-going affection (pp. 110, 105). ${ }^{14}$ Cavendish's exiled Wolsey adopts religious practices not previously part of his piety: on his journey north to York, he stays for some weeks at the Charterhouse at Richmond, where every day he attends prayers and where the monks 'by their counsel persuaded [him] from the vainglory of this world, and gave him divers shirts of hair, the which he often wore afterward' (p. 133).

Some commentators have taken the position that Wolsey's political subtlety was such that even Cavendish was occasionally deceived by the cardinal's true motives, and certainly Wolsey's self-abasement in his gentleman-usher's narrative is in part calculated to have the best chance of restoring the cardinal to favour (see, e.g., Wiley 1946). He explains to Cavendish that

it was most best way for me (all things considered) to do as I have done than to stand in trial with the King, for he would have

12.There is an eerie parallel between Anne, whom wolsey rebuked but who finds herself in a position to procure Wolsey's fall, and Wolsey, who as chancellor punishes Sir Amias Paulet, who put the future cardinal in the stocks when he was a schoolmaster (pp. 5-6).

13.For extensive discussion of the parallels between the first and second halves of Cavendish's text, see Sylvester (1960:47-53).

14.Cavendish himself is not nearly so reserved, asking because of Henry's 'carnal desire and voluptuous affection of foolish love... what surmised inventions hath been invented, what laws hath been enacted, what noble and ancient monasteries overthrown and defaced, [..., ] and what alternations of good and wholesome overthrown and defaced, $[. . .$,$] and what alternations of good and wholesome$
ancient laws and customs hath been tossed by will and willful desire of the prince, ancient laws and customs hath been tossed by will and willful desire
almost to the subversion and desolation of this noble realm' (p. 81). been loth to have been noted a wrong-doer. And in my submission the King (I doubt not) had a great remorse of conscience, wherein he would rather pity than malign me. (Cavendish 1962:141)

Wolsey's performance of his duties as archbishop of York is also, in Cavendish, devised in such a way as to reassure the king that the cardinal had learned his lesson. Plans for his installation in York Minster are 'not in so sumptuous a wise as his predecessors did before him', and en route to York Wolsey spends 2 days confirming children - the sort of quotidian pastoral duty that at the height of his power would have been beneath him (p. 148). The differences between Hall's and Cavendish's Wolseys are stark, and no doubt Cavendish had passages of Hall in mind as he narrated his master's downfall. Thus, for instance, Cavendish fashioned the scene of Wolsey's arrest in glaring contrast to Hall: while Wolsey does ask the Earl of Northumberland to see a copy of the commission to arrest him, he neither asserts clerical immunity nor attempts to excuse his actions, and once it is clear that a member of the king's privy chamber has come with the earl, he relents: '[Y]ou are a sufficient commission yourself.... Therefore I am ready to be ordered and disposed at your will' (p. 160).

The period from Wolsey's arrest to his death occupies two sentences in Hall, but nearly thirty pages in Cavendish. Far from suicide, it is clear that Wolsey's final illness comes from his shock at learning that the king has sent William Kingston, constable of the Tower, to conduct him back to the capital. Wolsey's conversations with Kingston reveal him to have glimpsed the nature of the king he has served: ' $[R]$ ather than he will either miss or want any part of his will or appetite, he will put the loss of one half of his realm in danger.' Wolsey's famous deathbed words, 'if I had served God as diligently as I have done the king, he would not have given me over in my grey hairs', likewise testify to his recognition of the true state of affairs between him and Henry (Cavendish 1962:183; see Sylvester 1960:58-62; Sylvester and \& Harding 1962:xii). Yet Wolsey is pensive and penitent more than bitter, and in Cavendish's telling his death is good and Christian. Not unlike Christ before the crucifixion, Wolsey predicts the hour when he will die. He confesses, receives the last rites, and passes away with dignity - all marks of the medieval ars moriendi. And when servants strip the cardinal's body for burial, they are surprised to find a shirt of hair under his fine linen (Cavendish 1962:186-187).

It must be emphasised that for all his sympathy toward the fallen Wolsey, Cavendish was not blind to his master's faults. Although there is not space here to multiply examples, many episodes in the Life present the cardinal as ambitious, concerned for pomp and ostentation, jealous of rivals, arrogant, and greedy - traits not unfamiliar from Hall. For Cavendish, Wolsey tempted fate with his worldly success, and so, even if he did not deserve his end, he risked his fall by trusting too much in the stability of good fortune and in the favour of an earthly king - a king who appears in Cavendish's pages as lustful, indecisive, self-absorbed, and 
at the end 'hated' by the cardinal (Cavendish 1962:193; see also Wiley 1946:126). Thus, in contrast to Hall, Cavendish presents a Wolsey who underwent a conversion, if not in the year between his dismissal as chancellor and the time of his arrest, then at least in the short span between his arrest and his death.

\section{Receiving Hall and Cavendish: Foxe, Stow, and Holinshed}

By the time of Queen Elizabeth's accession in 1558, two competing narratives about Wolsey were in circulation. Hall's was by far the more popular and closer to the Elizabethan establishment's own account of the queen's father's reign, but Cavendish's, first in manuscript and then in excerpts printed from 1580 onward, made substantial inroads and contributed to the development of portraits of the cardinal that were both more nuanced and more sympathetic.

That said, the 1570 edition of John Foxe's Actes and Monuments is innocent of influence from Cavendish. There is not space here for a thorough discussion of Foxe's teleological, providential, and nationalistic account of the restoration of the gospel to England, but it is worth examining how Foxe frames his narrative of Wolsey, which in large part he lifts from the pages of Hall, although he omits any reference to Anne Boleyn. ${ }^{15}$ Foxe interrupts his narrative of the persecution of 'simple men within the dioces of Lincolne' with what he entitles

A briefe discourse concerning the Storye and lyfe of Thomas Wolsey, late Cardinall of Yorke, by way of digression, wherin is to be seene and noted the expresse image of the proud vainglorious church of Rome, how farre it differeth from the true church of Christ Iesus. (Foxe 1570:1120b)

Indeed, Foxe continues, he wishes to tell Wolsey's story so that the 'pompe and pride' of the Roman church 'more notoriouslye may appeare to all men' (p. 1120b). The life of Wolsey, then, is a warning of the dangers of Roman Catholicism, dangers that in this part of Foxe's telling are more political and economic than theological. Certainly Foxe presents Wolsey as a pretender at church reform and as one who 'thought him selfe equall with the kyng', but his complaints primarily concern the quantities of money that Wolsey sent from England to Rome. Foxe adds to Hall's narrative the allegation that not only did Wolsey wish to support the besieged pope, but he even wished to be pope himself, and he spent English money meant to help rescue the pope on the pay of foreign soldiers - French soldiers, no less (p. 1123b). Even Henry's papal title, Defender of the Faith, Wolsey purchased with English money: ' $[I] \mathrm{t}$ cost more then [sic] London and $x l$. myle about it, considering $\mathrm{y}^{\mathrm{e}}$ great summes which you haue heard the Cardinall obteyned of the

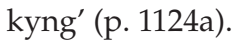

15.There is an extensive bibliography of studies of Foxe's martyrological writings: for few classic works relevant to Foxe's historical method, see Haller (1963), Bauckham (1978), Firth (1979).
Like Hall's Wolsey, Foxe's cardinal is unrepentant to the end. Foxe borrows from Hall the paragraphs in which he narrates Wolsey's begrudging journey to York, his prideful behaviour once there, and his arrogant invocation of clerical immunity in the face of arrest. But Foxe adds to Hall's account of Wolsey's final days a few details calculated to provoke disgust. Like Hall, Foxe repeats the rumour that Wolsey 'willingly tooke so much quantitie of a strong purgatio[n], that his nature was not able to beare it', but here, 'Also the matter that came from hym was so blacke, that the steining therof, could not be gotten out of hys blanckets by any meanes'. His corpse, moreover,

was blacke as pitch, and also was so heauy, $\mathrm{y}^{\mathrm{t}}$ vi. could scares beare it. Furthermore, it did so stincke aboue the ground, $\mathrm{y}^{\mathrm{t}}$ they were co[n]streyned to hasten the burial therof.

To add a final insult, 'At the which burial, such a tempest, with such a stincke there arose, that all the torches went out, and so he was throwen into the tombe'. Foxe reports that he learned all these details from 'one, yet beyung a lyue, in whose armes the sayd Cardinall dyed' (p. 1133a). His source cannot be identified with certainty, but it is clear that Foxe used the symbolic discourse of Christian hagiography especially a corpse that, most unlike the preserved body of a saint, decays more quickly than usual - to demonstrate that Wolsey was not in God's good graces and that his church is in fact the church of the devil.

In contrast to Foxe, John Stow brought together material from Hall's and Cavendish's accounts and created what we might call the first composite portrait of Wolsey, one that hesitates neither to condemn him for his failings nor to treat him sympathetically in disgrace. Stow's Chronicles of England (1580) explicitly cites both Hall and Cavendish, and in both the Chronicles and the more extensive Annales of England (1592) Stow treats the cardinal with what one scholar has called 'objectivity ... and comparative freedom from the bias against Wolsey so common in the sixteenth century' (Wiley 1946:128). Stow reprints many of Cavendish's narratives of Wolsey's journeys, banquets, servants, and household arrangements; as Wiley has noted, he omits from Cavendish's telling of the early part of Wolsey's life only the cardinal's dispute with Anne Boleyn over her dalliance with Percy (129). Stow does rely upon Hall for Wolsey's quarrels with the citizens of London, for popular opposition to Wolsey's tax policy, and the king's initial doubts about his marriage (Stow 1592:882-911). But Stow returns to Cavendish for the scenes at the legatine court, most significantly preserving Henry's disclaimer that it was not the cardinal who had prompted him to seek an annulment (Stow 1592:911ff.). Stow also keeps almost verbatim Cavendish's account of the fallen Wolsey, from the time of the cardinal's departure from York Place through his arrest and death, retaining as well Cavendish's implication that at the end, Wolsey realised his plight and regretted his unthinking obedience to a vicious king (941-942).

Stow's reliance upon Cavendish for the last years of Wolsey's life generates a sudden narrative shift when, after reprinting 
passages from the moralistic conclusion to the Life of Wolsey, he places the reader back in Hall's world, where as we have seen the cardinal's fall prefigures that of the Roman church. Hall had observed that ' $[t]$ he authoritie of this Cardinal set the clergie in such a pride that they dysdayned al men, wherefore when he was fallen thei followed', a claim that foreshadows the submission of the clergy and their payment of a $£ 100,000$ fine two paragraphs later. In Stow, the clergy do submit and tender this substantial sum, but there is little about the foregoing narrative that appears to warrant the payment of such a penalty (Hall 1550: fol. clxxxxiiii ; Stow 1592:942-943). The effect is to imply that the crown's actions against the clergy - and perhaps likewise against Wolsey - were not so much morally justified as politically expedient. It is not surprising, therefore, that Stow was investigated at least once for Roman Catholic sympathies. Although the charges against him were never substantiated, his familiarity with and willingness to use Cavendish's Life, alongside his refusal to repeat the most baseless accusations against Wolsey, suggests that he was somewhat sceptical of propagandistic evangelical versions of the cardinal's doings (Beer 2004).

It was through the works of Stow that the editors of the second edition of Raphael Holinshed's Chronicles had access to Cavendish's narrative; indeed, no part of Cavendish's Life not quoted in Stow makes an appearance in Holinshed. ${ }^{16}$ Wolsey's initial appearances in Holinshed are suffused with critical language, much of it personally as well as professionally censorious. Cavendish had told the story of how Wolsey was so dissatisfied with the appearance of the messenger sent from Rome to bring him his cardinal's hat that he apparelled him in finer clothes, and the gentleman-usher had marvelled, mostly approvingly, at how the reception of the hat 'was done in so solemn a wise as I have not seen the like unless it had been at the coronation of a mighty prince or king' (Cavendish 1962:17). However, in Holinshed, the story serves a sinister purpose, with Wolsey's creation as a cardinal furnishing an opportunity for comment on the public's hatred of him:

And now that he was thus a perfect cardinall, he looked aboue all estates, which purchased him great hatred and disdaine on all sides. For his ambition ws no lesse discernable to the eies of the people, than the sunne in the firmament in a cleere and cloudlesse summer daie ... for that his base lineage was both noted and knowne, in so much that his insatiable aspiring to supereminent degrees of dignitie kindled manifest contempt and detestation among such as pretended a countenance of good will and honourable dutie unto him, though in verie deed the same parties... would have tituled him a proud popeling; as led with the like spirit of swelling ambicion, wherewith the rable of popes had beene bladder like puffed and blowne up. (Holinshed 1587:837)

This final metaphor no doubt referred derogatorily to Wolsey's waistline as well as to his pride. Certainly Holinshed's

16.For the sake of convenience, I will be referring to the text of the second edition of the Chronicles as Holinshed's, though it was produced after his death in 1580 by Abraham Fleming and other contributors (Clegg 2015).
Wolsey, until the time of his fall, is a malignant character. Here the cardinal is responsible for the condemnation and execution of the Duke of Buckingham (pp. 862-865), his political dealings are corrupt, and when he perceives Henry's growing affection for Anne Boleyn, Wolsey not only writes to Rome to prohibit the divorce but even lies to the king about having done so (p. 909). In Holinshed's telling, like Hall's, it is Wolsey's deceptiveness that eventually provokes Henry to move against him.

Holinshed's narrative of Wolsey's fall is both textually and substantively a confused one. Quoting Stow (which is to say Cavendish ${ }^{17}$ ), he begins with the dukes of Norfolk and Suffolk demanding that Wolsey return the Great Seal. For the beginning of Wolsey's journey to York, he cites Hall instead, repeating the claim that Wolsey did not take well to his dismissal but was instead 'euer grudging at his fall' (Holinshed 1587:913). In what follows, Holinshed blends charming details about Wolsey's domestic life from Stow/ Cavendish with new criticisms that, if not in Hall's text, are very much in its spirit: for instance, Holinshed notes that Wolsey 'was not abashed' to ask the king to send him the set of liturgical vestments he had previously used at court (p. 915). For the cardinal's arrest, decline, and death Holinshed draws directly upon Stow/Cavendish, incorporating material from that source about Wolsey's apparent conversion. Yet the paragraph that concludes this section, in which Holinshed attempts to present the moral lessons of Wolsey's life, is a curious blend of Stow / Cavendish, Hall, and original analysis (p. 917).

All this might seem a fairly unremarkable blending of the opposing narratives of Cavendish and Hall, but then Holinshed appends a second assessment of Wolsey's life, this one attributed to the Jesuit martyr Edmund Campion. Campion describes Wolsey in terms that are themselves almost martyrological: he was

an aduancer of learning, stout in euerie quarrel, neuer happie till this his ouerthrow. Wherein he shewed such moderation, and ended so perfectlie, that the houre of his death did him more honor, than all the pompe of his life passed. (p. 917)

Holinshed's inclusion of Campion's praise without further comment suggests that he believed that Wolsey did indeed experience after his fall a kind of conversion, repudiating much of his earlier life. The Jesuit's eulogy prompts Holinshed to go back to the beginning of Wolsey's life and review the glories of his service as chancellor in a six-page narrative drawn almost entirely from Stow/ Cavendish (pp. 917-922). But once again Holinshed's narrative comes to an unusual conclusion, in an abrupt change of tone at the end of the Stow/Cavendish account of one of Wolsey's banquets. I have italicised here the portions from Stow/Cavendish:

And thus spent this cardinall his time from daie to daie, and yeare to year, in such wealth, ioie, triumph, and glorie, hauing always on his

17. Holinshed knew his source only as Stow, but we have seen that Stow draws nearly verbatim upon sections from Cavendish; therefore, in the remainder of this article, I will be referring to this source as Stow/Cavendish. 
side the kings especiall favour, until fortune enuied his prosperitie, and ouerthrew all the foundations of his glorie... euen to the verie losse of his life, which (as a man of a guiltie conscience, and fearing capitall punishment due by law for his undutiful demeanour against his souereigne) Edward Hall saith (upon report) he partlie procured, willinglie taking so great a quantitie of a strong purgation, as nature was therewith oppressed, and unable to digest the same; so that in fine he gaue up the ghost. (p. 922)

Holinshed's abrupt return to Hall from Stow/Cavendish is notable both for the contrast between the ostentation of Wolsey's prime and the disgrace of his end, as well as for its occlusion of Cavendish's explanation of the ultimate cause of the cardinal's downfall. In Cavendish, the italicised passage is followed immediately by the suggestion that Fortune 'procured Venus, the insatiate goddess, to be her instrument to work her purpose' by stirring up Henry's love for Anne and thereby creating the conditions for Wolsey's exile and death (Cavendish 1962:30). Of course, any narrative that questioned the legitimacy of Anne's marriage, and in consequence the legitimacy of Queen Elizabeth's birth, was anathema in late-16th-century England, and thus it is no surprise that Holinshed made the adjustments that he did.

\section{Dramatising the fall of Wolsey: Shakespeare's and Fletcher's Henry VIII (AII Is True)}

The second edition of Holinshed served as the primary source for one of the most influential theatrical renderings of the cardinal's story (Shakespeare \& Fletcher 2000:162). In William Shakespeare's and John Fletcher's Henry VIII (All Is True), both Wolsey's political glory and the tragedy of his fall and conversion reach new dramatic heights. ${ }^{18}$ A thorough discussion of the play is impossible here, but suffice it to note that critics differ with regard to its portrayal of Wolsey: some find that his character is 'ambivalently drawn', while others find him 'sharply depicted ... as villain and regenerate' (Champion 1979:12; Shakespeare \& Fletcher 2000:171). What is generally agreed is that Shakespeare and Fletcher create a sharp contrast between the proud Wolsey of the first half of the play and the disgraced Wolsey of the second scene of Act III, a contrast that one commentator has observed is so marked that it lacks 'a scene of transformation from one face to the other ... which would lend a genuinely dynamic quality to the characterization' (Champion 1979:12).

In the first two acts, Wolsey is preeminent and insuperable, procuring the downfall of the Duke of Buckingham by paying the duke's servants to testify against him, deceiving the king with regard to his having enacted the Amicable Grant, and when Henry repeals the levy, commanding his secretary to

18.The authorship of the play remains a topic of discussion: see Shakespeare and Fletcher (2000:180-199) and Law (1957) among many other studies. For a ful bibliography see Micheli (1988). Here, following McMullan, I will presume joint authorship by Shakespeare and Fletcher. tell the people that it was Wolsey, rather than the king, who had shown leniency. Toward the end of the first act Wolsey presides over a magnificent entertainment where the king fatefully meets Anne Boleyn. In Act II the cardinal continues at Henry's right hand: he procures from Rome the commission for Campeggio and himself to judge the king's marriage, and Henry, joyful to see him ('O my Wolsey,/The quiet of my wounded conscience,/Thou art a cure fit for a king'), dismisses the dukes of Norfolk and Suffolk from his presence (Shakespeare \& Fletcher 2000:2.2.72-2.2.74). Shakespeare and Fletcher borrow from Holinshed much of their narrative of the legatine court, but they imaginatively expand upon Holinshed's report, drawn from Cavendish, that Wolsey asked the king to publicly put to rest any rumour that the cardinal had provoked the king to seek his annulment; the play devotes more than 60 lines to this exchange between king and cardinal (2.4.140-2.4.206).

Wolsey's dominance, characterised by several scholars as Machiavellian (Brown 2013:138; Champion 1979:11; McBride 1977:30), comes to an abrupt end when, contrary to the cardinal's intent, the king receives a damning cache of documents, including an inventory of Wolsey's wealth and a letter to the pope arguing against the divorce. Holinshed presents a similar scene featuring Henry VII and the then-bishop of Durham, and the most recent editor of Henry VIII has noted as well a parallel between this scene and one in Foxe; to these sources we might add Hall's account of Wolsey's deceptiveness in his correspondence. ${ }^{19}$ Shakespeare and Fletcher compose a vigorous confrontation between Henry and Wolsey, at the end of which the king leaves Wolsey with the miscarried documents. Almost immediately the cardinal, admitting that he had sought to use his resources 'For mine own ends - indeed to gain the popedom', perceives that his career has run its course: 'I have touched the high point of all my greatness,/And from that full meridian of my glory/I haste now to my setting' (Shakespeare \& Fletcher 2000:3.2.212, 3.2.223-3.2.225). The confiscation of the Great Seal, a rehearsal of the charges against the cardinal, and news of the king's marriage to Anne follow in short order.

It is in a conversation between Wolsey and Thomas Cromwell, based loosely on Stow/Cavendish's account of their exchanges during the cardinal's exile, that Wolsey's repentance comes fully into view. He recognises that 'My high-blown pride/At length broke under me and now has left me,/Weary and old with service, to the mercy/Of a rude stream that must for ever hide me' (3.2.361-3.2.364). The cardinal confesses that he 'falls like Lucifer,/Never to hope again', in an allusion both to Wolsey's former brightness and, perhaps, to Holinshed's characterisation of Wolsey as 'luciferian' (3.2.371-3.2.372; see 356:n371). Curiously, though he knows that it was his own writings that furnished the king with evidence against him, Wolsey attributes his fall to Anne Boleyn: 'All my glories/In that one woman I have lost for ever' (3.2.408-3.2.409). But this is less an instance of 19.Shakespeare and Fletcher (2000:339, n. 124). See also p. 3 above. 
blame-laying than a recognition that Wolsey's sinful way of life was unsustainable ${ }^{20}$ :
Mark but my fall and that that ruined me.
Cromwell, I charge thee, fling away ambition.
By that $\sin$ fell the angels. How can man then,
The image of his maker, hope to win by it?
Love thyself last; cherish those hearts that hate thee.
Corruption wins not more than honesty. (3.2.439-3.2.444)

Wolsey's last words - 'Farewell,/The hopes of court: my hopes in heaven do dwell'- mark the completeness of his conversion. The Wolsey of Henry VIII does not die unrepentant, nor does he dwell for more than a few lines on his treatment by the king. Instead the cardinal acknowledges his faults and accepts his fate with something like the equanimity praised by Campion, advising Cromwell to 'Let all the ends thou aimest at be thy country's/Thy God's, and truth's', in contrast to Wolsey's more personal ambitions (3.2.447-3.2.448).

\section{Conclusion}

It is worth remarking that Henry VIII, which contains some of the sharpest depictions of Wolsey of the sources we have encountered, also portrays the cardinal's repentance and conversion as the most thoroughgoing. This unexpected contrast may be because of the ways in which the editors of Holinshed, who compiled Shakespeare's and Fletcher's chief source, brought together two disparate historiographical trajectories. As we have seen, Holinshed's chronicle combines, sometimes disjointedly, Hall's unflattering insinuations alongside Cavendish's loyal apologia for the fallen Wolsey. Elements of both trajectories were embellished as they moved from source to source, and by the time they reached the playwrights, they were ripe to be imaginatively interpreted in a way that produced the sharp contrast between the regnant cardinal of Acts I and II and the repentant cardinal of the second half of Act III.

Understanding the interrelationships between the texts we have been discussing is essential not only for the historiography of the Henrician Reformation, an historiography in which Wolsey has played an important, if variable, supporting role since the 1530s. Grasping how Wolsey's story was told in the 16th century is also essential for interpreting later portrayals of Wolsey, Henry, and other actors, because the chronicles of Hall, Foxe, Holinshed, and their contemporaries continued to serve as source materials for historians in the 17th century and beyond. Although this study cannot claim to be comprehensive, I hope that it has been able to show how an historiographically sensitive approach can reveal how Wolsey developed as a subject of historical writing and drama in the decades after his death. But if this article at least has demonstrated the value of careful, critical, yet sympathetic reading of texts from periods and mentalities other than our own, then at least it may be a

20.An alternative view is that of Kiefer (1979), who argues that Shakespeare and Fletcher suggested that Wolsey's fall was an instance of bad luck rather than mora reckoning fitting tribute to an extraordinary teacher, scholar, minister, ecumenist, and friend, Graham Duncan.

\section{Acknowledgements Competing interests}

The author declares that he has no financial or personal relationships that may have inappropriately influenced him in writing this article.

\section{References}

Anderson, J., 1984, Biographical truth: The representation of historical persons in Tudor-Stuart writing, Yale University Press, New Haven, CT.

Bauckham, R., 1978, Tudor apocalypse: Sixteenth century apocalypticism, millenarianism, and the English Reformation, Sutton Courtenay, Oxford.

Beer, B.L., 2004, 'Stow, John (1524/5-1605)', in Oxford dictionary of national biography, viewed 18 June 2015, from http://www.oxforddnb.com/view/ article/26611

Brown, G.S., 2013, Shakespeare's prince: The interpretation of the famous history of the life of King Henry the Eighth, Mercer University Press, Macon, GA.

Cameron, T.W., 1888, 'The early life of Thomas Wolsey', English Historical Review 3 , 458-477. http://dx.doi.org/10.1093/ehr/III.XI.458

Cavendish, G., 1962, 'The life and death of Cardinal Wolsey', in R.S. Sylvester \& D.P. Harding (eds.), 1962, Two early Tudor lives, pp. 1-193, Yale University Press, New Haven, CT.

Champion, L.S., 1979, 'Shakespeare's Henry VIII: A celebration of history', South Atlantic Bulletin 44(1), 1-18. http://dx.doi.org/10.2307/3198893

Clegg, C.S., 2015, 'Holinshed, Raphael (c. 1525-1580?)', in Oxford Dictionary of National Biography, viewed 18 June 2015, from http://www.oxforddnb.com/ view/article/13505

Dickens, A.G., 1989. The English Reformation, 2nd edn., Pennsylvania State University Press, University Park, PA

Duffy, E., 2005, The striping of the altars, 2nd edn., Yale University Press, New Haven, CT.

Edwards, A.S.G., 2014, 'Cavendish, George (b. 1494, d. in or before 1562?)', in Oxford Dictionary of National Biography, viewed 18 June 2015, from http://www. oxforddnb.com/view/article/4933

Firth, K.R., 1979, The apocalyptic tradition in reformation Britain, 1530-1645, Oxford University Press, Oxford.

Foxe, J., 1570, The ecclesiasticall history contaynyng the actes and monuments, John Day, London.

Gairdner, J., 1899, 'The fall of Cardinal Wolsey', Transactions of the Royal Historical Society new series, 13, 75-102.

Guy, J.A., 1982, 'Henry VIII and the praemunire manoeuvres of 1530-1531', English Historical Review 97, 481-503. http://dx.doi.org/10.1093/ehr/XCVII.CCCLXXXIV.481

Haigh, C., 1987, 'Anticlericalism and the English Reformation', in C. Haigh (ed.), The English Reformation revised, pp. 56-74, Cambridge University Press, Cambridge. http://dx.doi.org/10.1017/СBO9780511622113.005

Hall, E., 1550, Union of the two noble and illustre families of Lancaster and York, Grafton, London.

Haller, W., 1963, Foxe's book of Martyrs and the elect nation, J. Cape, London.

Herman, P.C., 2012, 'Hall, Edward (1497-1547),' in Oxford Dictionary of National Biography, viewed 18 June 2015, from http://www.oxforddnb.com/view/ article/11954

Holinshed, R., 1587, The First and Second Volumes of Chronicles, Henry Denham, London.

Kiefer, F., 1979, 'Churchyard's Cardinal Wolsey' and its influence on Henry VIII', Essays in Literature 6, 3-10.

Law, R.A., 1957, 'Holinshed and Henry the Eighth', Texas Studies in English 36, 3-11.

MacCulloch, D., 2004, Reformation: Europe's house divided, Penguin Books, New York, NY.

McBride, T., 1977, 'Henry VIII as Machiavellian Romance', Journal of English and Germanic Philology 76(1), 26-39.

Micheli, L.M., 1988, Henry VIII: an annotated bibliography, Garland, New York, NY and London.

Pollard, G., 1932, 'The bibliographical history of Hall's chronicle', Historical Research 10, 12-17. http://dx.doi.org/10.1111/j.1468-2281.1932.tb01889.x

Scarisbrick, J.J., 1968, Henry VIII, University of California Press, Los Angeles, CA.

Shakespeare, W. \& Fletcher, J., 2000, King Henry VIII, G. McMullan (ed.), Arden Shakespeare, London.

Steiner, G.F., 1952-53, 'A note on Cavendish's life of Cardinal Wolsey', English 9, 51-54. http://dx.doi.org/10.1093/english/9.50.51

Stow, J., 1592, The annales of England, Newbery, London. 
Sylvester R.S., 1960, 'Cavendish's life of Wolsey: The artistry of a Tudor biographer', Studies in Philology 57, 44-71.

Sylvester, R.S. \& Harding, D.P. (eds.), 1962, Two early Tudor lives, Yale University Press, New Haven, CT.
Waugh, W.T. 1922, 'The great statute of Praemunire', English Historical Review 37 173-205. http://dx.doi.org/10.1093/ehr/XXXVII.CXLVI.173

Wiley, P., 1946, 'Renaissance exploitation of Cavendish's life of Wolsey', Studies in Philology 43, 121-46. 